\title{
Nutrition therapy in Australia and New Zealand Intensive Care Units:
}

\section{An international comparison study}

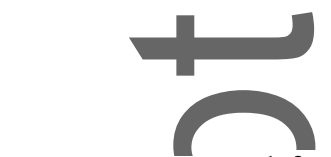

Emma J Ridley ${ }^{1,2} \mathrm{MPH}, \mathrm{APD}$

Sandra L Peake ${ }^{1,3,4}$ BMBS, PhD, FCICM

Matthew Jarvis ${ }^{4,5}$ MBBS

Adam M Deane ${ }^{1,6} \mathrm{MBBS}, \mathrm{PhD}$

Kylie Lange ${ }^{7} \mathrm{BSc}(\mathrm{Ma} \&$ CompSci) (Hons)

Andrew R $\overline{\text { Davies }}^{1}$ MBBS

Marianne Chapman ${ }^{4,5,7}$ BMBS, PhD, FCICM

Daren Heyland ${ }^{8} \mathrm{MD}, \mathrm{MSc}$

${ }^{1}$ Australian and New Zealand Intensive Care Research Centre, Department of Epidemiology

and Preventive Medicine, Monash University, Vic, Australia

${ }^{2}$ Nutrition Department, Alfred Health, Melbourne, Australia

${ }^{3}$ Department of Intensive Care, The Queen Elizabeth Hospital, Woodville, SA, Australia

${ }^{4}$ School of Medicine, University of Adelaide, SA, Australia

${ }^{5}$ Royal Adelaide Hospital, Adelaide, SA, Australia

${ }^{6}$ Intensive Care Unit, The Royal Melbourne Hospital, University of Melbourne, Australia

${ }^{7}$ Centre for Research Excellence in Translating Nutritional Science to Good Health,

Discipline of Medicine, University of Adelaide, SA, Australia

${ }^{8}$ Department of Critical Care Medicine Queen's University, Ontario, Canada

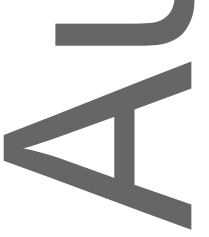

This is the author manuscript accepted for publication and has undergone full peer review but has not been through the copyediting, typesetting, pagination and proofreading process, which may lead to differences between this version and the Version of Record. Please cite this article as doi: 10.1002/jpen.1163.

This article is protected by copyright. All rights reserved. 


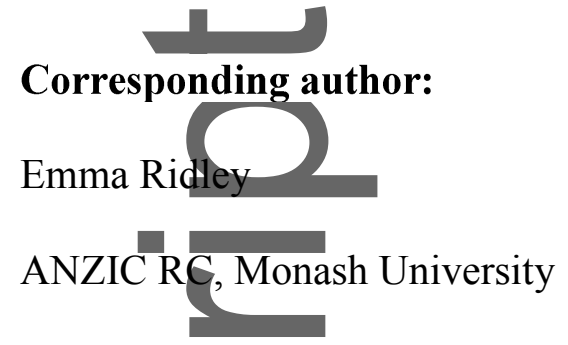

Level 3, 553 St:Kilda Road

Melbourne VIC 3004

emma.ridley@monash.edu

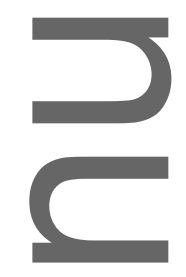

Financial disclosure:

There was no specific funding for this project. This work is part of $\mathrm{PhD}$ thesis and EJR has a National Health and Medical Research Council (NHMRC) postgraduate scholarship.

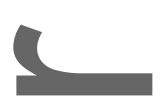

\section{Conflict of interest statement:}

The authors have no conflicts to declare.

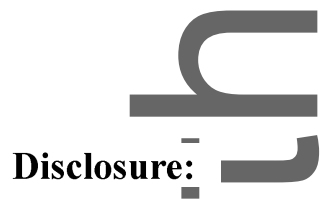

ER, SP, AD, ARD, MJC and KL are all investigators on the TARGET trial.

$\mathrm{AD}$ is an employee of Baxter Healthcare Corporation, Australia. EJR has received unrestricted research funding for an investigator initiated study from Baxter Healthcare Corporation. AD and MJC are on the management committee for this study. 


\section{ABSTRACT:}

Background: The Augmented versus Routine approach to Giving Energy Trial (TARGET) is the largest blinded enteral nutrition (EN) intervention trial evaluating energy delivery to be conducted in the critically ill. To determine the external validity of TARGET results, nutrition practices in intensive care units (ICUs) in Australia and New Zealand (ANZ) are described and compared to international practices.

Methods: Retrospective analysis of prospectively collected data for the International Nutrition Surveys, 2007-2013. Data are presented as mean (SD).

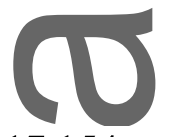

Results: 17,154 patients (ANZ: $n=2776$ vs. international $n=14378$ ) were included from 923 ICUs (146 and 777 respectively). EN was the most common route of feeding (ANZ: 85\%, $\mathrm{n}=2365$ patients vs international: $84 \%, \mathrm{n}=12$ 034, $\mathrm{p}=0.258$ ) and $\mathrm{EN}$ concentration was also similar $(<1.25 \mathrm{kcal} / \mathrm{ml}$ ANZ: 70\%, $\mathrm{n}=12396$ vs international: $65 \%, \mathrm{n}=56891$ administrations, $\mathrm{p}<0.001)$. Protein delivery was substantially below the estimated prescriptions but similar between the regions $(0.6(0.4) \mathrm{g} / \mathrm{kg} /$ day vs $0.6(0.4) \mathrm{g} / \mathrm{kg} / \mathrm{day}, \mathrm{p}=0.849)$. Patients in ANZ received slightly more energy (1133 (572) vs 948 (536) kcal/day, p <0.001), possibly because more energy lwas prescribed (1947 (348) vs 1747 (376) kcal/day, p<0.001), nutrition protocols were more commonly used $(98 \%$ vs $75 \%, \mathrm{p}<0.001)$ and included recommendations for therapies such as prokinetic agents $(87 \%$, vs $51 \%, n=399, \mathrm{p}<0.001)$, and small bowel feeding ( $62 \%$ vs $40 \%$ p <0.001) compared to international ICUs. 


\section{Conclusions:}

Key elements of nutrition practice are similar in ANZ and international ICUs. These data can be used to determine the external validity and relevance of the TARGET results.

\section{Clinical relevancy statement:}

The Augmented versus Routine approach to Giving Energy Trial (TARGET) is the largest blinded enteral nutrition intervention trial to be conducted in the critically ill. 4000 critically ill patients in Australia and New Zealand (ANZ) have been randomized to energy dense $(1)$

$(1.5 \mathrm{kcal} / \mathrm{ml})$ enteral nutrition or routine care to evaluate whether increasing energy delivery (1)

effects clinical outcomes. To determine the external validity of the TARGET results we have compared ANZ and international nutritional practices. These data are important for critical care clinicians throughout the world to interpret the upcoming TARGET results.

\section{INTRODUCTION}

The provision of nutrition therapy to critically ill patients is a widely accepted international standard of care ${ }^{1-5}$. Practice guidelines assist clinicians to implement evidence based nutrition therapy and generally recommend that nutrition, delivered via an enteric tube (termed enteral nutrition (EN)), be started within 24-48 hours of admission to the intensive care unit (ICU) in the hemodynamically stable patient ${ }^{1-5}$. Delivery of nutrition in this way has been associated with reduced infective complications, length of ventilation, time in the ICU and mortality ${ }^{1-4}$. Beyond these elements however, there exists several areas of uncertainty due to lack of definitive evidence, specifically, the effect of nutrition risk, use of indirect calorimetry vs predictive equations, optimal timing of nutrition, the amount of energy and protein to provide, and how best to optimise nutrition delivery. This uncertainty leaves leaving recommendations contained in best practice guidelines open to significant interpretation and confusion. 
One of the largest areas of area of uncertainty is the amount of energy to provide to critically ill patients to elicit optimum clinical outcomes. The Augmented versus Routine approach to Giving Energy Trial (TARGET) is the largest blinded enteral nutrition intervention trial evaluating energy delivery to be conducted ${ }^{6}$. The primary aim of this trial TARGET is to determine if augmentation of energy delivery using energy dense EN (a $1.5 \mathrm{kcal} / \mathrm{ml} \mathrm{EN}$ solution) improves 90-day survival when compared to routine care. Whilst this trial is only being conducted in Australia and New Zealand (ANZ), the pragmatic nature of the intervention provides the opportunity for these data to be generalizable to international nutrition practice. It is however plausible that the current lack of definitive evidence regarding the role of energy and other key elements of nutrition practice in critical illness has resulted in significant temporal and geographical heterogeneity in practice. Thus, prior to the publication of TARGET and to establish external validity of the results, it is important to describe nutrition practices in ANZ and compare this to practice in international ICUs, with a focus on choice of EN solution and energy delivery.

\section{METHODOLOGY}

This was a retrospective analysis of data collected prospectively as part of the International Nutrition Survey (INS), a quality improvement activity coordinated by The Clinical Research Evaluation Unit (CERU), Ontario, Canada. Data were obtained for the survey annually from years 2007 to 2013 inclusive (with the exception of 2010 and there was no survey in 2012). The methods of this survey have previously been described in detail ${ }^{7}$. In summary, participation in the survey was voluntary, provided ICUs had at least 8 beds and a person with knowledge and ability to collect data. Available survey data included demographics on the hospital, ICU and nutrition service, as well as individual patient nutrition therapy 
information for a maximum of 12 days. Consecutive patients who had mechanical ventilation initiated in the first 48 hours of ICU stay and remained in ICU for more than 72 hours were eligible for inclusion in the survey. Management of the patient was according to the individual clinicians in the ICUs. Data obtained for this analysis were: (1) hospital and ICU organisation details; (2) detailed nutrition assessment information (which was only collected in survey years 2011 and 2013); (3) daily nutrition provision information; and (4) outcome information.

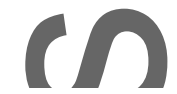

Mode of nutrition therapy delivered on a study day was defined when a patient received EN, parenteral nutrition $(\mathrm{PN})$ or oral nutrition alone or in any combination and each patient could contribute a minimum of 0 days and a maximum of 12 days. For each patient, a maximum of 3 unique EN solutions (as defined in the INS methodology) were collected during an EN study day (which have been defined as 'EN administrations' for the purpose of this analysis). Caloric content of EN solutions was confirmed using product information. If information was unavailable, it was unclear how the solution was being delivered or it was specifically designed to be a 'supplemental' product, the solution was excluded. EN solutions were grouped according to calorie content for analysis $(\mathrm{kcal} / \mathrm{ml}):<1.25$ (defined as standard EN solution); 1.25 to $1.49 ; 1.5$ to $1.99 ; \geq 2$. To simplify the description, methods to determine weight for the purpose of energy and protein estimations, and the choice of predictive equations were described as the most popular choice if $\geq 80 \%$ of the patients underwent the same method at the site level and otherwise were defined as 'mixed' if the site did not report the same method for $\geq 80 \%$ of the patients included in the analysis. Days where transition to permanent oral nutrition was noted have been excluded, as has day of discharge/death.

ICUs in ANZ were defined as those self-identified as being located in ANZ and international sites were defined as all other sites that did not identify as an ICU in ANZ. 
Ethics approval for the larger survey was obtained by the CERU at Queens University, Canada and if required, by individual sites for each participating year of the survey. Further approvals were not required for this secondary analysis of data.
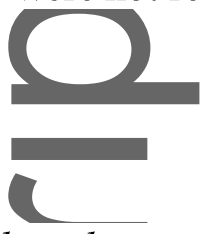

Statistical analysis

Categorical data are reported as numbers and percentages (\%). Continuous data are reported 10

as mean (standard deviation (SD)) where normally distributed or as median and interquartile range $[\mathrm{IQR}]$ where not normally distributed. Site characteristics are compared between regions using chi-square tests for categorical variables and 2-sample t-tests or Mann-Whitney tests for continuous data. Patient characteristics are compared using generalized estimating equations (GEE). Logistic and ordinal regression were used for categorical data and linear regression for continuous data, accounting for the clustering of patients within sites. Duration of mechanical ventilation and length of stay were censored at 60 days and log transformed for analysis. Time to discharge alive was censored at 60 days and analyzed via a log-rank test with death treated as a competing event. Analysis of EN administrations was done via a GEE logistic regression with clustering of administrations within patients, and patients within sites. Analysis was performed using SPSS version 22 and a two- sided p-value of 0.05 was considered to be statistically significant. Because sites may have participated in the survey in multiple years, a sensitivity analysis was repeated for energy and protein delivery only including data from the most recent survey from each site. Sensitivity analyses were also conducted to assess potential differences over the five survey years in the use of methods for estimating energy requirements and in the caloric content of EN administrations by including year and year-by-region fixed effects in the analysis models. 


\section{RESULTS}

\section{Overall site and patient characteristics}

Patient characteristics are shown in Table 1 and site characteristics in Table 2. There were 923 ICUs in the data set from all survey years (146 from ANZ and 777 international), from 592 unique sites (70 from ANZ and 177 international) contributing 17154 patients (2776 from ANZ and 14378 international). Of sites from ANZ, 48\% had participated once in the survey and $52 \%$ had participated multiple times, and for international sites it was $67 \%$ and $33 \%$ respectively.

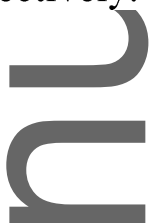

Nutrition assessment

Overall, the mean percentage of patients per site in the analysis who received a nutrition assessment was $88 \%(26 \%)(n=7228)$. The mean proportion of patients who had a nutrition assessment was less in ANZ sites compared to international ICUs ( $80 \%$ (28\%), $\mathrm{n}=75$ vs $88 \%$ (25\%), $\mathrm{n}=340$ sites, $\mathrm{p}=0.001)$ and sites in ANZ were less likely to primarily use actual weights in energy estimations compared to international ICUs $(13 \%, n=18$, vs $30 \%, n=230$ sites, $\mathrm{p}<0.001)$. The preferred methods to estimate energy requirements differed between ANZ and international ICUs; in ANZ ICUs, the Schofield equation" and 'mixed methods' were the most common choices (both $33 \%, n=47$ ) whereas in international ICUs the weight based energy estimation ${ }^{9}$ was the most common primary method $(47 \%, n=385)$. There were no significant differences in usage over the 5 survey timepoints, except for the weight based energy estimation (year-by-region, $\mathrm{p}=0.016$ ). When the weight based method was compared across years within each region the statistical differences did not remain (ANZ 34\% in 2007 to $47 \%$ in 2013 ; International $51 \%$ in 2007 to $47 \%$ in 2013 , $>>0.95$ for both). 
The mean calorie and protein prescription differed between ICUs (Energy: 1947 (348) calories in $\widehat{\mathrm{ANZ}}$ vs 1747 (376) calories internationally, $\mathrm{p}<0.001$ and protein; $1.12(0.25)$ $\mathrm{g} / \mathrm{kg} /$ day in ANZ vs $1.17(0.31) \mathrm{g} / \mathrm{kg} /$ day internationally, $\mathrm{p}<0.001$. Table 1 and 2 report further nutrition assessment information.

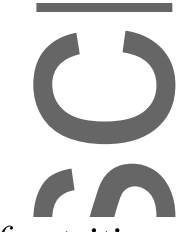

Mode of nutrition and choice of EN solution

EN was the most common mode of nutrition delivery overall (84\%, n=14 399 patients) and this was similar across regions (ANZ: $85 \%, n=2365$ patients and international: $84 \%, n=12$ 034, $\mathrm{p}=0.258$ ) however EN was commenced earlier in ANZ; 19.3 [8-38] hours after admission compared to 28 [14-54] hours in international ICUs, $\mathrm{p}<0.001$. The percentage of patients receiving PN was also similar (ANZ: $20 \%, n=544$ and international: $21 \%, n=3024$, $\mathrm{p}=0.331)$ but oral nutrition was provided more commonly in ANZ (43\%, $\mathrm{n}=1196$ vs $31 \%$, $\mathrm{n}=4476$ patients, $\mathrm{p}<0.001$ ). Figure 1 demonstrates combinations of nutrition therapy provided during the study period.

Information on caloric content was available in $90 \%(n=105515)$ of the 117891 EN administrations. Overall, the most commonly used EN solution in both ANZ (70\% of administrations, $n=12$ 396) and international ICUs (65\% of administrations, $n=56891$, $<0.001)$ was a standard solution $(<1.25 \mathrm{kcal} / \mathrm{ml})$. Figure 2 provides further data on EN solution preference. There was no significant change over time in the use of any caloric density in the sensitivity analysis (year-by-region interaction and year $\mathrm{p}>0.05$ ), with administrations of standard solution $(<1.25 \mathrm{kcal} / \mathrm{ml})$ ranging from $71 \%$ in 2007 to $67 \%$ in 2013 in ANZ, and 68\% in 2007 to 63\% in 2013 internationally. 


\section{Adequacy of nutrition delivery}

In ANZ patients, total energy delivery (from EN, PN and propofol) was slightly more than internationally (1133 (572) calories or 15 (8) kcal/kg/day vs 948 (536) calories or 13 (8) $\mathrm{kcal} / \mathrm{kg} /$ day, $\mathrm{p}<0.001)$. However, protein delivery was similar in the two populations (46 (26) g or $0.6(0.4) \mathrm{g} / \mathrm{kg} /$ day g vs $44(28) \mathrm{g}$ or $0.6(0.4) \mathrm{g} / \mathrm{kg} / \mathrm{day}, \mathrm{p}=0.85)$. Figure 3 shows daily energy and protein over the 12 day study period.

When excluding surveys from repeat contributing sites for the sensitivity analysis, the small point estimate differences between ANZ and international community for both energy delivery and protein became less (total energy 1086 (583) kcal/day or 14.0 (7.8) kcal/kg/day vs. 949 (538) or 13.2 (7.9); p=0.064; and total protein 44 (26) g/day or $0.57(0.35) \mathrm{g} / \mathrm{kg} / \mathrm{day}$ vs $44(28)$ or $0.60(0.39)) \mathrm{g} / \mathrm{kg} / \mathrm{day}, \mathrm{p}=0.131)$

\section{Nutrition service}

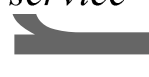

Nutrition therapy protocols were reported in $79 \%(\mathrm{n}=717)$ of ICUs in the analysis but were more common in ANZ ICUs $(98 \%, \mathrm{n}=143$ vs $75 \%, \mathrm{n}=564, \mathrm{p}<0.001)$ than those located internationally and the contents recommendations for management of nutrition significantly differed. ANZ ICUs more commonly reported the inclusion of prokinetic agents $(87 \%, n=127$ vs $51 \%, n=399, p<0.001)$, small bowel feeding tubes $(62 \%, n=90$ vs $40 \%, n=314, p<0.001)$, withholding of $\overparen{E N}$ for clinical procedures $(52 \%, n=76$ vs $35 \%, n=272, p<0.001)$.

It was more common to have a dietitian in an ANZ ICU compared to an international ICU (93\% vs $81 \%, p=0.001)$, however, if a dietitian was present, the mean full time equivalent 
(FTE) per 10 beds was lower in ANZ sites compared to international sites $(0.32(0.20)$ vs $0.46(0.32)$ FTE), $p<0.001)$. Further nutrition service information can be viewed in Table 2.

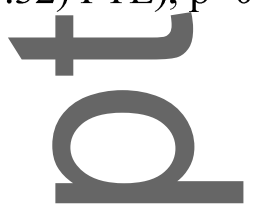

Interruptions to EN delivery

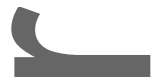

EN was interrupted in more ANZ patients than internationally $(72 \%, n=1695$ vs $59 \%$, $\mathrm{n}=7103, \mathrm{p}=<0.001$ ), with the most common reason being for a procedure (ANZ: $69 \%$, $\mathrm{n}=1173$ vs $61 \%, \mathrm{n}=4361, \mathrm{p}=<0.00)($ Table 3$)$.

Clinical outcomes

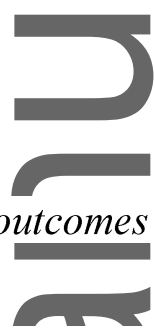

Clinical outcome data are shown in Table 4.

\section{DISCUSSION}

Summary of main findings

This is the first study to compare nutrition practice in ANZ to international practice. Overall, differences were observed in nutrition assessment techniques, nutrition service and delivery details, however many of these were modest. The route of delivery and the type of EN formula used were similar between regions. Energy delivery was slightly higher in ANZ ICUs, but significantly below predicted energy requirements in both regions. This may be because predicted energy requirements were higher and practice within ANZ more frequently utilised a protocol which included elements recommended in best practice guidelines to increase energy delivery, or, there may be population characteristics which are contributing. While differences were observed, they were modest, and such observations are important as 
in general, they support the external validity of TARGET results and can be used in interpretation and application of the findings.

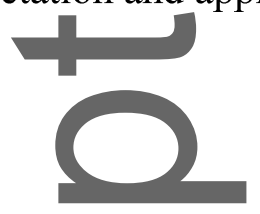

How does this fit with current literature?

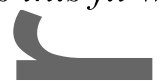

Sites in ANZ prescribed and delivered higher amounts of energy compared to international sites; however, the overall provision of energy and protein in both regions remained substantially less than the estimated requirements. The delivery of less than recommended energy and protein during critical illness is a consistent observation regardless of region investigated and/or different survey data are used ${ }^{10-13}$. Importantly, this establishes that the group randomised to receive routine care in TARGET, as identified in the pilot trial, represents standard practice within ANZ and internationally ${ }^{14}$. Several practice issues have previously been described as contributing to nutrition inadequacy in critical illness and may be contributing in this analysis; interruptions to EN (which were frequently observed in this study and a feature of nutrition therapy guidelines in ANZ ICUs); delayed initiation of nutrition; and gastrointestinal intolerance ${ }^{15,16}$. An alternate explanation for the persistent nutrition inadequacy may be that clinicians have decided to stop advocating for meeting nutrition goals beyond that achieved in standard care until definitive evidence is available regarding the optimal energy and protein target in critical illness.

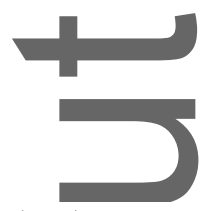

A standard concentration $(<1.25 \mathrm{kcal} / \mathrm{ml})$ EN solution was the most commonly prescribed solution in both ANZ and international sites. The frequent use of a standard concentration EN solution has previously been documented in observational data from ANZ ${ }^{17}$. Although there was a slightly higher use of standard formulae in the ANZ group, which was statistically 
significant due to the large numbers analysed, the difference was numerically inconsequential.

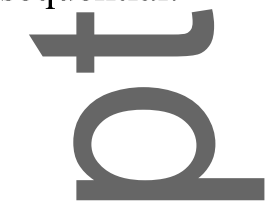

\section{Implications for clinical practice and research}

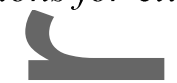

This study demonstrates that the use of a standard concentration EN solution $(<1.25 \mathrm{kcal} / \mathrm{ml})$ is the most commonly used formula and that delivery of energy and protein is substantially 10

below estimated requirements throughout the world. The exact amount of energy and protein to be delivered (and how this relates to an estimated or measured target) is one of the fundamental unanswered questions in critical care nutrition; TARGET will be the largest blinded enteral nutrition trial conducted in the critically ill and will thus provide important evidence as to the role of energy delivery during the acute phase of critical illness. If provision of energy close to recommended goal is beneficial in critical illness, the strategy applied in TARGET (which delivers a $1.5 \mathrm{kcal} / \mathrm{ml}$ EN solution at the same goal rate as a 1 $\mathrm{kcal} / \mathrm{ml}$ solution) has the potential to be widely adopted without a major change in feeding principles 14 . Finally, this study has identified that in ANZ there is a considerable proportion of patients ingesting oral nutrition, with or without supplemental tube liquid enteral nutrient. This poses a new challenge for clinicians in both practice and research. Little is currently understood regarding the management and optimisation of oral intake during critical illness, with several small studies indicating significant difficulties for multifactorial reasons ${ }^{18,}{ }^{19}$. This remains to be investigated in future work.

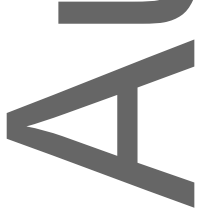

There are several plausible explanations for the difference in energy delivery observed between the two regions, which should be considered when interpreting the results. The 
increased energy delivery in ANZ patients may be due to differences in specific aspects of nutrition management and the patient population. Compared to international ICUs, sites in (

ANZ reported greater dietitian presence and more use of nutrition protocols. The protocols more commonly included elements associated with improved nutrition delivery as recommended by best practice feeding guidelines. The differences in protocol content may account for the shorter time to commencing EN and the increased prescribed and delivered energy in the ANZ cohort, however evidence for the role of nutrition protocols in both increasing energy delivery and in improving clinical outcomes is conflicting ${ }^{20,21}$. This may thus explain the observation of varied existence and content of nutrition therapy protocols. Further, the lack of definite evidence in many areas of critical care nutrition practice makes definitive practice recommendations difficult and may also contribute to the differing contents reported in protocols. Alternatively, the higher proportion of overweight and obese patients in ANZ compared to international ICUs may also account for the higher energy delivery (due to the higher energy aim).

Strengths and limitations

This a large dataset that provide valuable information of international and ANZ specific nutrition delivery and informing the generalizability of future nutrition trials conducted in ANZ such as TARGET. There are however some potential limitations. This study was observational and uses data that were collected for quality improvement activities. As such, the data collection is unlikely to be as robust as that collected as part of a clinical trial and we were limited by the information available. Further, this was a retrospective analysis and is therefore subject to the limitations associated with an analysis of this type. Many ICUs participated over multiple years, and when adjusted for in a sensitivity analysis the moderate 
difference between ANZ and international energy and protein delivery were even less. Accordingly, ANZ ICUs interested in nutrition may have been more likely to participate in the survey and therefore exacerbate any differences that exist. It must also be noted that in the analysis, all ICUs from regions outside of ANZ were grouped together to form the international cohort. Regions that are larger may therefore be influencing the results more than smaller regions, and there may also be differences in practice between smaller regions which were not described with this method. Nutrition risk in critically ill patients may influence the prescription and response to artificial nutrition therapy ${ }^{22,23}$. We were unable to assess any relationship between prescription practices and nutrition risk due to limited survey data on nutrition risk. And importantly, practice may have changed since the last and over the duration of the survey years, with the first survey being performed 10 years ago and the last, 5 years ago. Despite this possibility, the data from the INS is the largest and most comprehensive data available to inform on current nutrition therapy practice. Finally, it is also possible that different practices in medical management and service delivery which were not collected as part of the survey explain some of the differences between the two regions, such as greater energy delivery and proportion of patients receiving oral nutrition.

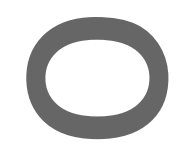

It must also be acknowledged that due to the size of the database, many variables were statistically significant in their comparisons but were not always clinically important. Specifically, the energy difference observed $(187 \mathrm{kcal} /$ day or $2 \mathrm{kcal} / \mathrm{kg} / \mathrm{day})$ was relatively minor and it seems intuitively unlikely that such a difference will result in meaningful improvements in patient centered outcomes. This must be considered in the interpretation of the results. 
The data also suggest that the cohort in ANZ may be less unwell than the international cohort, supported by more favourable clinical outcomes in the ANZ population, although T

many of the differences were modest and probably statistically significant only due to the size of the sample. This may also partially explain better energy delivery in the ANZ cohort; clinicians may have prioritised nutrition delivery earlier and/or EN tolerance may have been greater in a less sick cohort. These slight differences in population should however be considered when applying the results of the TARGET trial to populations outside of ANZ.

\section{CONCLUSION}

Differences were observed in nutrition assessment, service and delivery between ANZ and international ICUs; however, such differences were modest and while statistically significant they may not be clinically meaningful. Overall, key elements of nutrition practice in ANZ that relate to design aspects of TARGET appear sufficiently similar to international practice to ensure external validity and relevance of the TARGET results to the international community.

\section{References}

1. Heyland DK, Dhaliwal R, Drover JW, Gramlich L, Dodek P. Canadian clinical practice guidelines for nutrition support in mechanically ventilated, critically ill adult patients. SPEN J Parenter Enteral Nutr. Sep-Oct 2003;27(5):355-373.

2. Kreymann KG, Berger MM, Deutz NE, et al. ESPEN Guidelines on Enteral Nutrition: Intensive care. Clin Nutr. Apr 2006;25(2):210-223.

3. McClave SA, Taylor BE, Martindale RG, et al. Guidelines for the Provision and Assessment of Nutrition Support Therapy in the Adult Critically Ill Patient: Society of 
Critical Care Medicine (SCCM) and American Society for Parenteral and Enteral

Nutrition (A.S.P.E.N.). JPEN J Parenter Enteral Nutr. Feb 2016;40(2):159-211.

4. Reintam Blaser A, Starkopf J, Alhazzani W, et al. Early enteral nutrition in critically

ill patients: ESICM clinical practice guidelines. Intensive Care Med. Mar

2017; 43(3):380-398.

5. Singer P,Berger MM, Van den Berghe G, et al. ESPEN Guidelines on Parenteral Nutrition. intensive care. Clin Nutr. Aug 2009;28(4):387-400.

6. The TARGET Investigators on behalf of the Australian and New Zealand Intensive

Care Society Clinical Trials Group. Study protocol for The Augmented versus

Routine Approach to Giving Energy Trial (TARGET). Crit Care \& Resus. March

2018;20(1): 15-22.

7. Alberda 0 , Gramlich L, Jones N, et al. The relationship between nutritional intake and clinical outcomes in critically ill patients: results of an international multicenter observational study. Intensive Care Med. Oct 2009;35(10):1728-1737.

8. Schofield WN. Predicting basal metabolic rate, new standards and review of previous work. Hum Nutr Clin Nutr. 1985;39 Suppl 1:5-41.

9. Cerra FB, Benitez MR, Blackburn GL, et al. Applied nutrition in ICU patients. A consensus statement of the American College of Chest Physicians. Chest. Mar 1997;111(3):769-778.

10. Cahill NE, Dhaliwal R, Day AG, Jiang X, Heyland DK. Nutrition therapy in the critical care setting: what is "best achievable" practice? An international multicenter observational study. Crit Care Med. Feb 2010;38(2):395-401.

11. Heyland DK, Dhaliwal R, Wang M, Day AG. The prevalence of iatrogenic underfeeding in the nutritionally 'at-risk' critically ill patient: Results of an international, multicenter, prospective study. Clin Nutr. Aug 2015;34(4):659-666. 
12. Bendavid I, Singer P, Theilla M, et al. NutritionDay ICU: A 7 year worldwide prevalence study of nutrition practice in intensive care. Clin Nutr. Aug 2017;36(4):1122-1129.

13. Vallejo KP, Martínez CM, Matos Adames AA, et al. Current clinical nutrition practices in critically ill patients in Latin America: a multinational observational study. Critical Care. 2017;21(1).

14. Peake SE, Davies AR, Deane AM, et al. Use of a concentrated enteral nutrition solution to increase calorie delivery to critically ill patients: a randomized, doubleblind, clinical trial. Am J Clin Nutr. Aug 2014;100(2):616-625.

15. Passier RH, Davies AR, Ridley E, McClure J, Murphy D, Scheinkestel CD.

Periproeedural cessation of nutrition in the intensive care unit: opportunities for improvement. Intensive Care Med. Jul 2013;39(7):1221-1226.

16. Chapman MJ, Deane AM. Gastrointestinal dysfunction relating to the provision of nutrition in the critically ill. Curr Opin Clin Nutr Metab Care. Mar 2015;18(2):207212.

17. Peake SL, Chapman MJ, Davies AR, et al. Enteral nutrition in Australian and New Zealand intensive care units: a point-prevalence study of prescription practices. Crit Care Resusc. Jun 2012;14(2):148-153.

18. Chapple LS, Deane AM, Heyland DK, et al. Energy and protein deficits throughout hospitalization in patients admitted with a traumatic brain injury. Clin Nutr. Dec 2016;35(6):1315-1322.

19. Merriweather J, Smith P, Walsh T. Nutritional rehabilitation after ICU - does it happen: a qualitative interview and observational study. J Clin Nurs. Mar 2014;23(56):654-662. 
20. Doig GS, Simpson F, Finfer S, et al. Effect of evidence-based feeding guidelines on mortality of critically ill adults: a cluster randomized controlled trial. JAMA. Dec 17 2008;300(23):2731-2741.

21. Martin CM, Doig GS, Heyland DK, Morrison T, Sibbald WJ, Southwestern Ontario Critical Care Research N. Multicentre, cluster-randomized clinical trial of algorithms for eritical-care enteral and parenteral therapy (ACCEPT). CMAJ. Jan 20 2004;170(2):197-204.

22. Heyland DK, Dhaliwal R, Jiang X, Day AG. Identifying critically ill patients who benefit the most from nutrition therapy: the development and initial validation of a novel risk assessment tool. Critical Care (London, England). 2011;15(6):R268.

23. Rahman A, Hasan RM, Agarwala R, Martin C, Day AG, Heyland DK. Identifying critically-11 patients who will benefit most from nutritional therapy: Further validation of the "modified NUTRIC" nutritional risk assessment tool. Clin Nutr. Feb 2016;35(1):158-162.

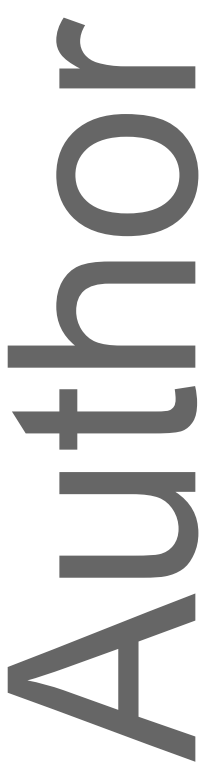


Figure 1: Mode of nutrition delivery during study period ANZ:

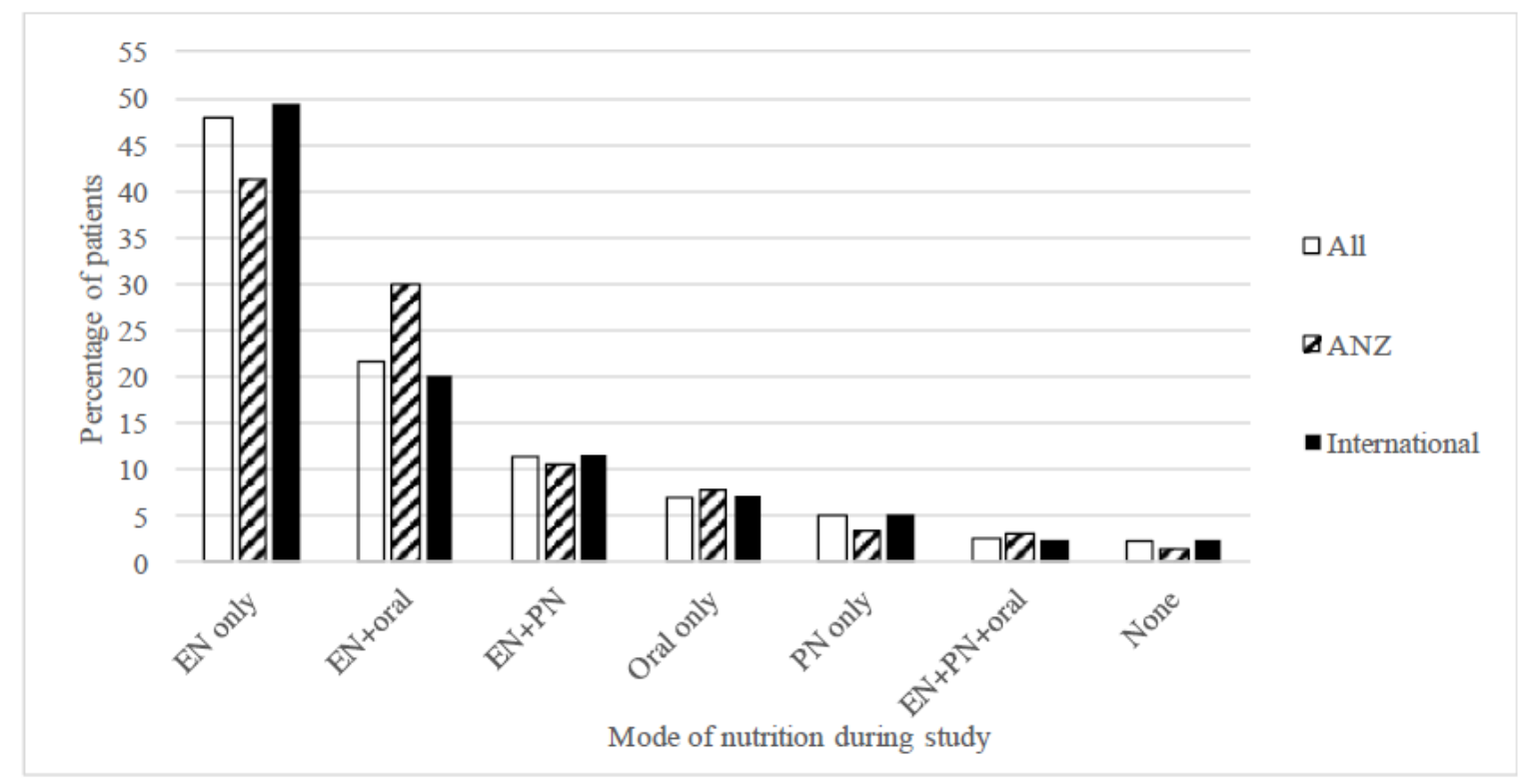

Figure 2: Caloric content of prescribed EN solutions during the study period
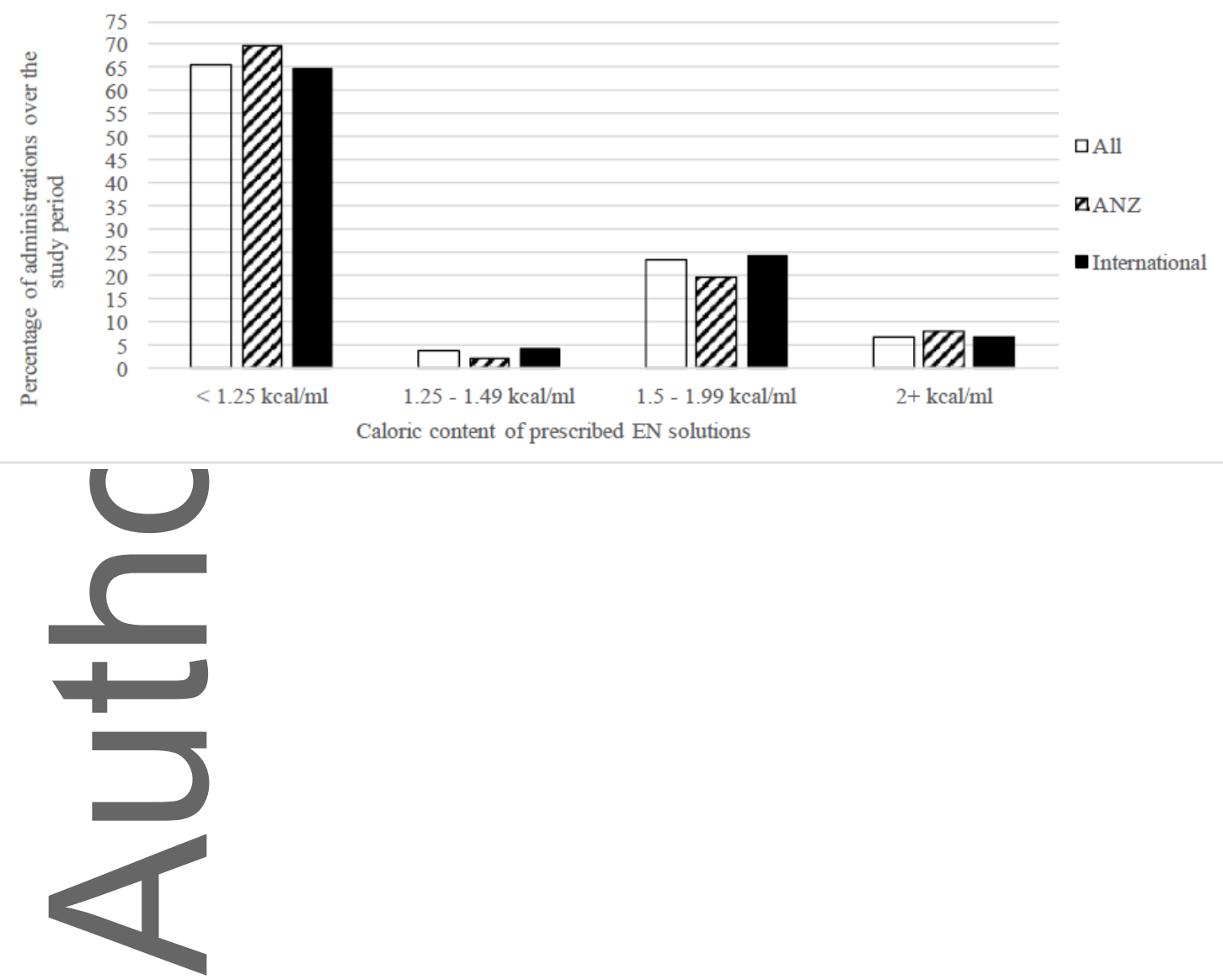

This article is protected by copyright. All rights reserved. 
Figure 3: Daily energy (Panel A) and protein delivery (Panel B) over the study period from all sources in the whole cohort, Australia and New Zealand and international Intensive Care Units. Data is presented as mean (SE).
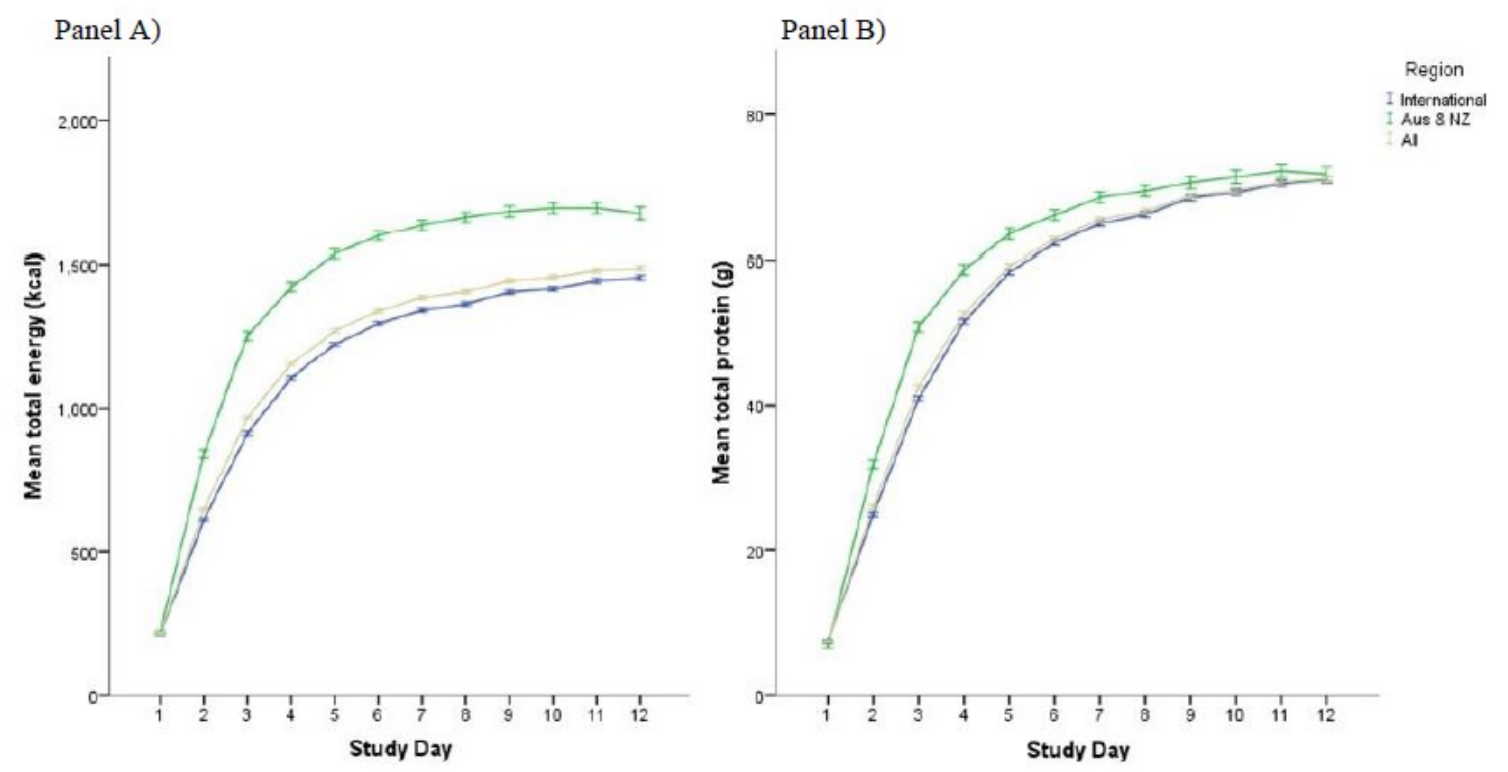

Table 1: Patient characteristics

\begin{tabular}{|c|c|c|c|c|}
\hline Characteristic & $\begin{array}{l}\text { Overall } \\
\mathrm{n}=17154\end{array}$ & $\begin{array}{l}\text { ANZ } \\
\mathrm{N}=2776\end{array}$ & $\begin{array}{l}\text { International } \\
\mathrm{N}=14378\end{array}$ & P-value \\
\hline $\begin{array}{l}\text { Proportion of patients by site location, } \mathrm{n}(\%) \\
\text { ANZ } \\
\text { Canada } \\
\text { Lurope \& Sth Africa } \\
\text { Asia America }\end{array}$ & $\begin{array}{l}2776(16) \\
3231(19) \\
4906(29) \\
2403(14) \\
1270(7) \\
2568(15)\end{array}$ & $\mathrm{n} / \mathrm{a}$ & $\mathrm{n} / \mathrm{a}$ & $\mathrm{n} / \mathrm{a}$ \\
\hline $\begin{array}{l}\text { Age, years, mean (SD) } \\
\text { Gender, male, } n(\%)\end{array}$ & $\frac{60(18)}{10347(60)}$ & $\begin{array}{l}58(18) \\
1737(63)\end{array}$ & $\begin{array}{l}60(18) \\
8610(60)\end{array}$ & $\begin{array}{l}<0.001 \\
0.011\end{array}$ \\
\hline $\begin{array}{l}\text { BMI, } \mathrm{kg} / \mathrm{m}^{2} \text {, mean (SD) } \\
\text { Underweight }(<18.5 \mathrm{~kg} / \mathrm{m} 2), \mathrm{n}(\%) \\
\text { Normal }(18.5-24.9 \mathrm{~kg} / \mathrm{m} 2), \mathrm{n}(\%) \\
\text { Overweight }(25-29.9 \mathrm{~kg} / \mathrm{m} 2), \mathrm{n}(\%) \\
\text { Obese }(30+\mathrm{kg} / \mathrm{m} 2), \mathrm{n}(\%)\end{array}$ & $\begin{array}{l}27(8) \\
863(5) \\
6849(40) \\
4965(29) \\
4393(26)\end{array}$ & $\begin{array}{l}28(7) \\
109(4) \\
968(35) \\
901(33) \\
775(28)\end{array}$ & $\begin{array}{l}27(8) \\
754(5) \\
5881(41) \\
4064(28) \\
3618(25)\end{array}$ & $\begin{array}{l}0.003 \\
<0.001\end{array}$ \\
\hline $\begin{array}{l}\text { Admission type, n (\%) } \\
\quad \text { Medical }\end{array}$ & $10866(63)$ & $1612(58)$ & 9254 (64) & 0.003 \\
\hline
\end{tabular}




\begin{tabular}{|c|l|l|l|l|}
\hline \multicolumn{1}{|c|}{$\begin{array}{l}\text { Surgical emergency } \\
\text { Surgical elective }\end{array}$} & $\begin{array}{l}140(24) \\
2147(13)\end{array}$ & $\begin{array}{l}720(26) \\
444(16)\end{array}$ & $\begin{array}{l}3420(24) \\
1703(12)\end{array}$ & \\
\hline $\begin{array}{l}\text { Admission Diagnosis, } \mathrm{n}(\%) \\
\text { Medical: Respiratory }\end{array}$ & $4151(24)$ & $526(19)$ & $3625(25)$ & $<0.001$ \\
$\quad \begin{array}{l}\text { Surgical: Gastrointestinal } \\
\text { Medical: Sepsis }\end{array}$ & $1896(11)$ & $364(13)$ & $1532(11)$ & 0.009 \\
\hline APACHE II Score, median (IQR) & $22(16-27)$ & $21(16-26)$ & $22(17-27)$ & 0.001 \\
\hline $\begin{array}{l}\text { Energy and protein requirements, mean (SD) } \\
\text { Prescribed energy requirements (kcal/day) }\end{array}$ & $1780(379)$ & $1947(348)$ & $1747(376)$ & $<0.021$ \\
$\begin{array}{l}\text { Prescribed energy requirements } \\
\text { (kcal/kg/day) }\end{array}$ & $24(6)$ & $25(5)$ & $24(6)$ & $<0.001$ \\
$\begin{array}{l}\text { Prescribed protein requirements (g/day) } \\
\text { Prescribed protein requirements (g/kg/day) }\end{array}$ & $88(25)$ & $87(21)$ & $88(26)$ & 0.851 \\
\hline
\end{tabular}

APACHE: Acute Physiology and Chronic Health Evaluation II; BMI: Body mass index; IQR: Interquartile range; kcal: Kilocalorie; SD: Standard deviation

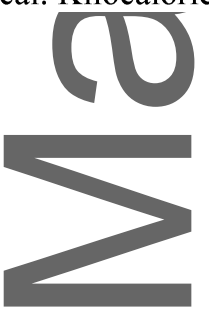

Table 2: Site and nutrition assessment characteristics (data is by site)

\begin{tabular}{|c|c|c|c|c|}
\hline Characteristic & $\begin{array}{l}\text { Overall } \\
\mathrm{n}=923\end{array}$ & $\begin{array}{l}\text { ANZ } \\
N=146\end{array}$ & $\begin{array}{l}\text { International } \\
\mathrm{N}=777\end{array}$ & P-value \\
\hline $\begin{array}{l}\text { Location of international sites, } \mathrm{n}(\%) \\
\text { Canada } \\
\text { Europe \& Sth Africa } \\
\text { Latin America } \\
\text { Asia }\end{array}$ & $\mathrm{n} / \mathrm{a}$ & $\mathrm{n} / \mathrm{a}$ & $\begin{array}{l}171(19) \\
270(29) \\
129(14) \\
64(7) \\
143(16)\end{array}$ & $\mathrm{n} / \mathrm{a}$ \\
\hline Hospital size, beds, mean (SD) & $595(407)$ & $525(225)$ & $608(432)$ & 0.540 \\
\hline ICU size, beds, mean (SD) & $18(10)$ & $16(8)$ & $18(10)$ & 0.390 \\
\hline $\begin{array}{l}\text { Contents of feeding protocol, yes, } \mathrm{n}(\mathrm{9} \\
\text { Head of bed elevation } \\
\text { GRV, ml, mean (SD) }\end{array}$ & $\begin{array}{l}562(61) \\
246(90)\end{array}$ & $\begin{array}{l}79(54) \\
242(79)\end{array}$ & $\begin{array}{l}483(62) \\
247(92)\end{array}$ & $\begin{array}{l}0.067 \\
0.364\end{array}$ \\
\hline BGL and insulin protocol, yes, $\mathrm{n}(\%)$ & $795(86)$ & $113(77)$ & $682(88)$ & $<0.001$ \\
\hline
\end{tabular}

This article is protected by copyright. All rights reserved. 


\begin{tabular}{|c|c|c|c|c|}
\hline BGL targets in protocols, mmol/L, mean (SD) & & & & \\
\hline Upper & $8.5(1.6)$ & $8.9(1.4)$ & $8.4(1.7)$ & 0.004 \\
\hline Lower 1 & $4.9(1.2)$ & $5.0(1.3)$ & $4.9(1.2)$ & 0.562 \\
\hline Weight used in energy estimation, $\mathrm{n}(\%)$ & & & & \\
\hline Actual & $248(27)$ & $18(13)$ & $230(30)$ & $<0.001$ \\
\hline Estimated & $40(4)$ & $8(6)$ & $32(4)$ & 0.472 \\
\hline Ideal based on BMI $20-25 \mathrm{~kg} / \mathrm{m} 2$ & $46(5)$ & $9(6)$ & $37(5)$ & 0.489 \\
\hline Mixed-use & $511(57)$ & $97(67)$ & $414(54)$ & 0.004 \\
\hline Method to estimate energy requirements, $\mathrm{n}(\%)$ & & & & \\
\hline Schofield Equation ${ }^{7}$ with adjustment for stress and/or & $66(7)$ & $47(33)$ & $28(3)$ & $<0.001$ \\
\hline Weight based $^{8}$ & $426(44)$ & $41(29)$ & $385(47)$ & $<0.001$ \\
\hline Mixed-use & $268(28)$ & $47(33)$ & $221(27)$ & 0.360 \\
\hline
\end{tabular}

EN: Enteral nutrition; ICU: Intensive care unit; kcal: Kilocalorie; SD: Standard deviation

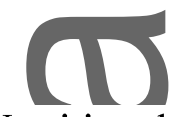

able 3: Nutrition delivery information (data is by patient)

\begin{tabular}{|c|c|c|c|c|}
\hline Characteristics & $\begin{array}{l}\text { Overall } \\
\mathrm{n}=17154\end{array}$ & $\begin{array}{l}\text { ANZ } \\
\mathrm{N}=2776\end{array}$ & $\begin{array}{l}\text { International } \\
\mathrm{N}=14378\end{array}$ & P-value \\
\hline \multicolumn{5}{|l|}{$\begin{array}{l}\text { Energy and protein delivery from EN during study period, } \\
\text { mean (SD) }\end{array}$} \\
\hline Energy from EN (kcal/day) & $745(553)$ & $855(596)$ & $724(542)$ & $<0.001$ \\
\hline Protein from EN (g/day) & $36(28)$ & $38(27)$ & $36(28)$ & 0.075 \\
\hline \multicolumn{5}{|l|}{$\begin{array}{l}\text { Percentage of energy and protein requirements provided } \\
\text { during the study period, mean (SD) }\end{array}$} \\
\hline Energy requirements met by EN & $42(31)$ & $44(30)$ & $42(31)$ & \\
\hline Protein requirements met by EN & $42(31)$ & $44(30)$ & $42(31)$ & 0.111 \\
\hline Energy requirements met by $\mathrm{EN}+\mathrm{PN}+$ propofol & $56(30)$ & $59(28)$ & $55(30)$ & 0.006 \\
\hline Protein requirements met by $\mathrm{EN}+\mathrm{PN}$ & $52(30)$ & $53(28)$ & $52(31)$ & 0.205 \\
\hline $\begin{array}{l}\text { EN interrupted during study, yes, } \mathrm{n}(\%) \\
\text { Reasons for interruptions, } \mathrm{n}(\%)\end{array}$ & $8796(61)$ & $1695(72)$ & $7103(59)$ & $<0.001$ \\
\hline Fasting for procedure & $5534(63)$ & $1173(69)$ & $4361(61)$ & $<0.001$ \\
\hline Intolerance to EN & $2291(26)$ & $418(25)$ & $1873(26)$ & 0.129 \\
\hline Other & $2328(26)$ & 405 (24) & 1923 (27) & 0.387 \\
\hline
\end{tabular}




\begin{tabular}{|l|l|l|l|l|}
\hline Duration of interruptions to EN, hours, mean (SD) & & & \\
$\begin{array}{l}\text { Total duration of EN interruptions } \\
\text { Duration of EN interruptions per 24 }\end{array}$ & $22(18)$ & $23(19)$ & $21(18)$ & 0.224 \\
\hline
\end{tabular}

EN: Enteral nutrition; ICU: Intensive care unit; PN: Parenteral nutrition; kcal: Kilocalorie; SD: Standard deviation

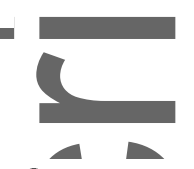

Table 4: Outcomes

\begin{tabular}{|c|c|c|c|c|}
\hline Characteristics & Overall & ANZ & International & P-value \\
\hline \multicolumn{5}{|l|}{ Mortality to 60 days, died, n (\%) } \\
\hline ICU & $3299(19)$ & $383(14)$ & $2916(20)$ & $<0.001$ \\
\hline Hospital & $4360(25)$ & $557(20)$ & $3803(26)$ & $<0.001$ \\
\hline $\begin{array}{l}\text { Duration of mechanical ventilation, } \\
\text { days, median [IQR] }\end{array}$ & $7[3-15]$ & $6[3-12]$ & $7[3-16]$ & $<0.001$ \\
\hline \multicolumn{5}{|l|}{ Length of stay, days } \\
\hline ICU & $10[6-19]$ & $9[5-17]$ & $11[6-20]$ & 0.001 \\
\hline Hospital & $24[13-52]$ & 26 [14- 49] & $24[13-53]$ & 0.212 \\
\hline \multicolumn{5}{|l|}{ Time to discharge alive } \\
\hline ICU & 16 [7- undefined $]$ & $11[6-28]$ & 14 [7- undefined] & $<0.001$ \\
\hline Hospital & 38 [16-undefined] & 34 [16- undefined] & 40 [16 - undefined $]$ & $<0.001$ \\
\hline
\end{tabular}

ICU: Intensive care unit; IQR: Interquartile range;

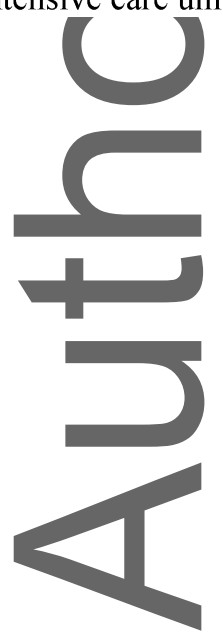




\section{University Library}

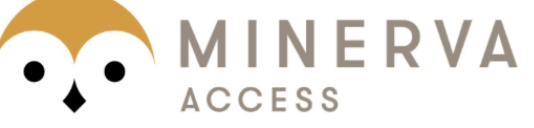

A gateway to Melbourne's research publications

Minerva Access is the Institutional Repository of The University of Melbourne

Author/s:

Ridley, EJ;Peake, SL;Jarvis, M;Deane, AM;Lange, K;Davies, AR;Chapman, M;Heyland, D

Title:

Nutrition Therapy in Australia and New Zealand Intensive Care Units: An International Comparison Study

Date:

2018-11-01

Citation:

Ridley, E. J., Peake, S. L., Jarvis, M., Deane, A. M., Lange, K., Davies, A. R., Chapman, M. \& Heyland, D. (2018). Nutrition Therapy in Australia and New Zealand Intensive Care Units: An International Comparison Study. JOURNAL OF PARENTERAL AND ENTERAL NUTRITION, 42 (8), pp.1349-1357. https://doi.org/10.1002/jpen.1163.

Persistent Link:

http://hdl.handle.net/11343/284456 